\title{
PRODUCTION IN GDLRC and PRESENT REFLECTIONS
}

\author{
A.KISA ${ }^{\mathrm{a}}$, S.ÇOLAK ${ }^{\mathrm{a}}$, S.BAKICI ${ }^{\mathrm{a}}$, L.ÖZMÜŞa \\ ${ }^{\text {a }}$ Department of Mapping, General Directorate of Land Registry and Cadastre, 06450 Oran Ankara, Turkey \\ akinkisa@gmail.com \\ scolak2000@gmail.com \\ sbakici@tkgm.gov.tr \\ lozmus@gmail.com
}

Commission II, WG II/2

KEY WORDS: Cadastre Renovation Project (CRP), Near infrared images, orthophoto, image services.

\begin{abstract}
:
Recently, Turkey's National Geographic Information System (TNGIS) carried out a more comprehensive studies. General Directorate of Land Registry and Cadastre (GDLRC) within the scope of these studies has projects in many areas within the jurisdiction. GDLRC have started Land Registry and Cadastre Modernization Project (LRCMP) in 2008 and still continues this project. The current project is very successful in the renewal and transfer of digital media, after the completion of the country's digital cadastre. The scope of this project was prepared comprehensive study. The scope of this project was prepared comprehensive study.
\end{abstract}

This studies; human resources development, new cadastre offices renovation and its services improvement, examining and reporting of the valuation of real estate, renovation and updating of the cadastre. All works continues at the same speed and determination. With these developments, GDLRC works with institutions, organizations and citizens. These developments cause a further increase interoperability and trust relationships. GDLRC, across the country, produces, stores, manages and preservesof property information. GDLRC the use and development of real estate is an important way to the work. In this context, one of the layers of spatial information systems, an essential requirement of the images which obtained by means of remote sensing satellite photos and / or consist of aerial photographs, is quite an important role. In research, in order to meet the common needs of different institutions and organizations, aerial photographs and orthophoto imagery are needed. Aerial photographs more up to date, precise, clear and reliable.

GDLRC, signing of important projects, is working to implement the Orthophoto Information System (OIS) project. GDLRC equipped with a new photogrammetric systems in 2009. In this way, the technological advances in the industry leading on this issue very closely monitored and carried out the task successfully. $200,000 \mathrm{~km}^{2}$ area in the country, 1/5000 scaled digital color orthophoto images were producedbetween 2009-2012. Orthophoto images of other areas is carried out by General Command of Mapping (GCM). Orthophotos, base images with the current covering the whole country, cloudless, 30-45 cm in the sampling interval (Ground Sample Distance - GSD), produced will be realized by both institutions in 2014. Ongoing projects in the fields covered by the renewal is important. Orthophoto production stage, stereo, color, and near-infrared aerial photographs of the terrain elevation models are also available. Municipalities places by $1 / 1000$ scale orthophoto images prepared in this process.

The production of orthophotos, digital cadastral works of engineering projects and other institutions, decision-support processes, quality controls and integrity of the legal dimension of the feature can be used to create litter. GDLRC for these purposes by the OGC Web Services standards TNGIS prepared and successfully created the image layer. Two projects planned by GDLRC. In both of projects, historical aerial photographs, are retrieved from GDLRC and GCM archives, will scan, produce orthophoto and service from web. 


\section{Introduction}

Since the early 2000s, GDLRC launched projects to create an infrastructure for spatial information in the realization of many projects. Land Registry and Cadastre Information System (TAKBIS) Completion of Cadastre, Turkey's National Geographic Information System Infrastructure Installation Project, Land Information Archive Scanning (TARBISS), TUSAGA-Active Project, LRCMP, orthophoto Information System are some of these projects (http://www.tkgm.gov.tr).

GDLRC in general, the most important parts of TNGIS levels producing basic spatial studies, manages, develops and must provide the map service the country's other institutions and organizations. Map production monitoring center, geodetic infrastructure, cadastre, orthophoto is a part of the basic layers.

Satellite images and / or aerial photographs which is one of the indispensable layers of spatial information systems, is quite important in this context. In GDLRC signing of important projects in this regard, studies are carried out to implement the orthophoto Information System project.

GDLRC, with new technological advances in photogrammetric systems are monitored very closely and successfully carried out the task in this regard the locomotive industry. Since 2009, 1/5000 digital color orthophoto images are produced at $210,000 \mathrm{~km} 2$ area in the country. Other areas of the orthophoto images are manufactured by GCM. Orthophotos produced by both institutions in 2014, with the whole country, covering the current, clear, quality checks were made, in the sampling interval of 30 to $45 \mathrm{~cm}$ will be realized in the production of the image base. Significant and ongoing projects in the priority areas covered by the reproduction of orthophotos. Orthophoto production stage, stereo, color, and nearinfrared aerial photographs of the terrain elevation models are also available. Municipalities places by $1 / 1000$ scale orthophoto images prepared in this process.

Orthophotoscan be used in engineering projects of other institutions, especially with the work of digital cadastral decision-support processes, quality controls and as a base for legal processes. GDLRC prepared and successfully created the image layer of TNGIS for these purposes by the OGC Web Services standards.

There are historic aerial photographs within GDLRC and GCM archives. 1:5000 scale aerial photographs were taken to produce Standard Topographic (ST) maps. Scale is $1: 16000$ and 1:35000. It will be produced and will be served orthophoto using aerial photographs.

\section{Spatial Information Systems and Infrastructure Projects of GDLRC}

There are many sectors in our country that work with spatial data. The most basic need of these sectors is having a healthy, safe, easy and quick accessible system. Each sector is establishing a spatial information systemin its field $s$. The INSPIRE directive came into force on 15 May 2007 and will be implemented in various stages, with full implementation required by 2019 .

The INSPIRE directive aims to create a European Union (EU) spatial data infrastructure. This will enable the sharing of environmental spatial information among public sector organisations and better facilitate public access to spatial information across Europe.

A European Spatial Data Infrastructure will assist in policy-making across boundaries. Therefore the spatial information considered under the directive is extensive and includes a great variety of topical and technical themes (http://inspire.jrc.ec.europa.eu/).

INSPIRE is based on a number of common principles:

Data should be collected only once and kept where it can be maintained most effectively.

- It should be possible to combine seamless spatial information from different sources across Europe and share it with many users and applications

- It should be possible for information collected at one level/scale to be shared with all levels/scales; detailed for thorough investigations, general for strategic purposes.

- Geographic information needed for good governance at all levels should be readily and transparently available.

- Easy to find what geographic information is available, how it can be used to meet a particular need, and under which conditions it can be acquired and used.

Appendices to this purpose, in order of priority, and rules were published. It was released in the order of priorities, institutions or organizations that work across the country to carry out tasks that work to prepare the bodies.

Works on biilding Turkey's national spatial information is carried out by the relevant authorities in accordance with the INSPIRE Directive. GDLRC fulfills its duties rapidly and performs for future (Figure 1).

Issued by the Prime Minister in 2003, building up TNGIS No. $2003 / 48$ by Circular started to execute within the scope of e-Transformation Turkey Project Short-Term Action Plan was initiated. Action Plan "in order to establish Turkey's National Geographic Information System Making A Preliminary Study on" General Directorate of Land Registry and Cadastre action number 
47 of "is given the responsibility. In 2005, the State Planning Organization, "in coordination with No. 2005/5 on the Supreme Planning Council Action Plan on eTransformation Turkey Project was published in 2005. The action plan for the installation of the Turkey national geographic information infrastructure, "Turkey's National Geographic Information System Infrastructure Preparatory Studies for Setting-Up" on the General Directorate of Land Registry and Cadastre number 36 is given the task of carrying out the action. Turkey's National Geographical Information System Infrastructure Modernization of Public Administration in the period of 2007-2008 -75 work on setting up the application (RGB75) and the "Geographic Information System Infrastructure" project has been launched. Infrastructure related to the project to establish TNGIS "Feasibility Study Preparation" service, Law No. 67 of 5809 within the meaning of Turksat A.Ş. was initiated as a direct purchase. In December 16, 2009 Turksat and GDLRC signed "Feasibility Study Preparation" agreement and the project was completed successfully. Turkey's National Geographic Information System Infrastructure Establishment Project to prevent the production of repetitive data, the project of reciprocal data use and most importantly, access to accurate and up-to-date geographic data via latest technology was aimed. The project was delivered to General Directorate of Geographic Information Systems after completion (K1sa et all., 2011).

GDLRC have launched TAKBIS in 2001 for digitizing land registry and cadastre information to provide and manage. The project'sthe first and second phase have ended and the preparations for the third phase is completed. (http://www.tkgm.gov.tr).

TUSAGA-Active Project, the entire country and K.K.T.C. throughout the 24-hour real-time (RTK) to determine the sensitivity of the geographical location $\mathrm{cm}$, cadastre and land use maps of the International Terrestrial Reference Frame (ITRF) conducted between 2006-2009 with the aim to convert, which is the basis for all projects across the country being intensively used spatial (http://www.tkgm.gov.tr).

TKMP has started in 2008 and is still continuing. Following the completion of the country's digital cadastre with the current cadastre, the current project is very successful in the renewal and transfer of digital media. Recent and comprehensive study was prepared within the scope of this project, land registry and cadastre offices improvement of the services provided and prepared a comprehensive report examining the valuation of real estate, human resources development, TAKBİS finding the opportunity to spread the work over a larger area, the main base of 1/5000 scale digital color orthophoto maps produced, property cadastre and cadastral works are completed the renovation work continues at the same speed and determination (http://www.tkgm.gov.tr).

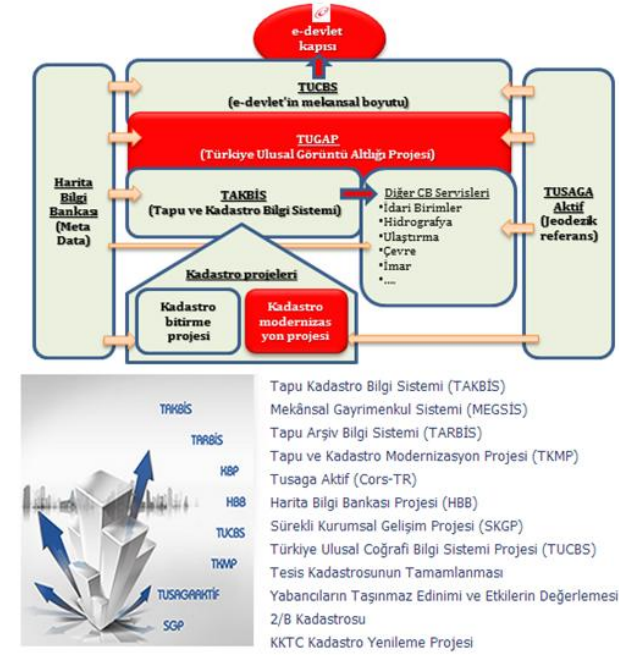

Figure 1. Projects of GDLRC

Orthophoto requirements of spatial information systems is an quite important in this regard. GDLRC orthophoto Information System project implemented. This project will meet the orthophoto request of other institutions and organizations.

These developments GDLRC doing business with institutions, organizations and citizens co-operation leads to a further increase interoperability and trust relationships. All property information across the country that produce, store, manage and protect an organization rooted in the GDLRC, spatial use and development of real estate in the country's future with the important work tasks are directed to the locomotive.

\section{Photogrammetric mapping and orthophoto production GDLRC Studies Photogrammetric mapping and orthophoto production}

GDLRC is an institution started to work by purchasing four photogrammetric mapping photogrammetry tool from Wild firm in 1952. In various areas across the country since 1954, 1/5000 scale maps have been produced (Figure 2).

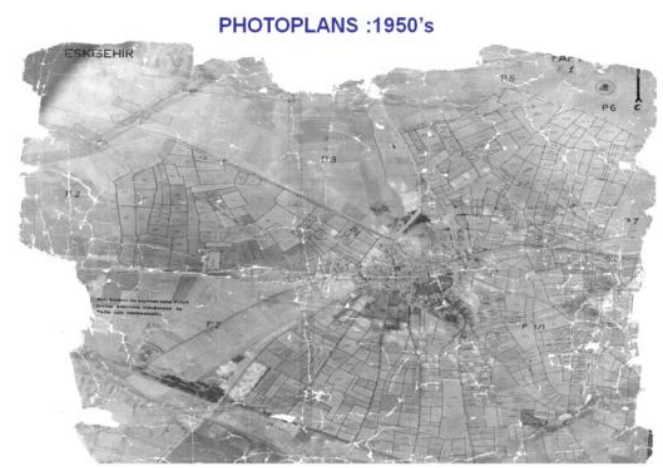

Figure 2. Photo plan sample from 1950 
From 1960 to 1990 , covering the whole of Turkey, ST maps weres completed in 70\% (Figure 4).

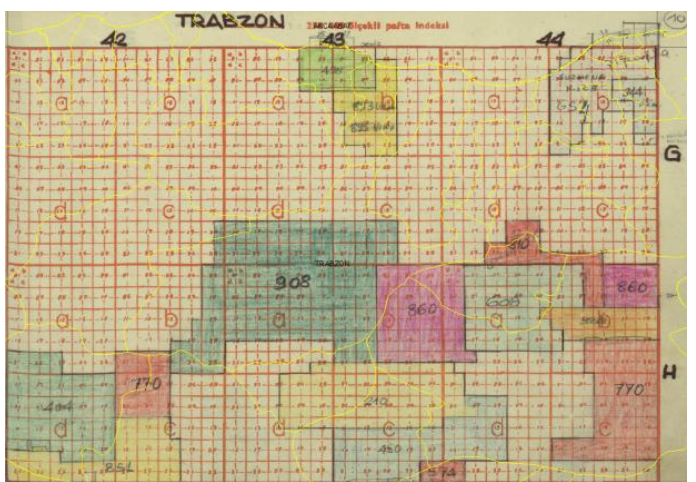

Figure 3. 1:250000 scale Trabzon sheet production index

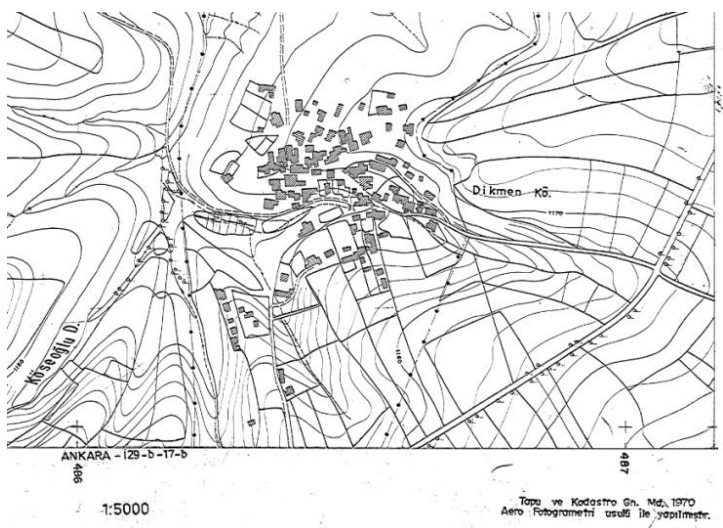

Figure 4. 1:5000 scale standard topoğrafik map

Aerial photography for the production of various scale photogrammetric mapping during 1990-2000 were done. In this context, the analog system, the location of production in 1996, replaced by the analytical systems (http://www.tkgm.gov.tr).

Within the context of ARIPand Merlis projects (http://www.tkgm.gov.tr) 1/5000 scale photogrammetric and color orthophoto maps were produced between 20002008 (Figure 5).

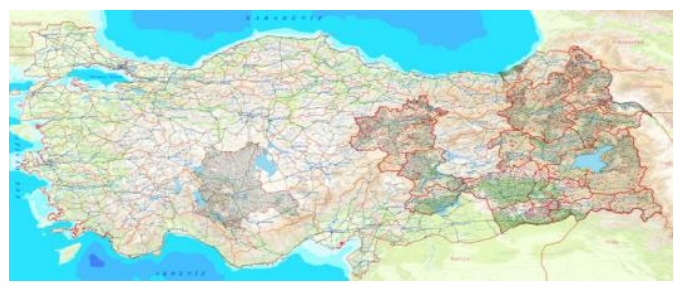

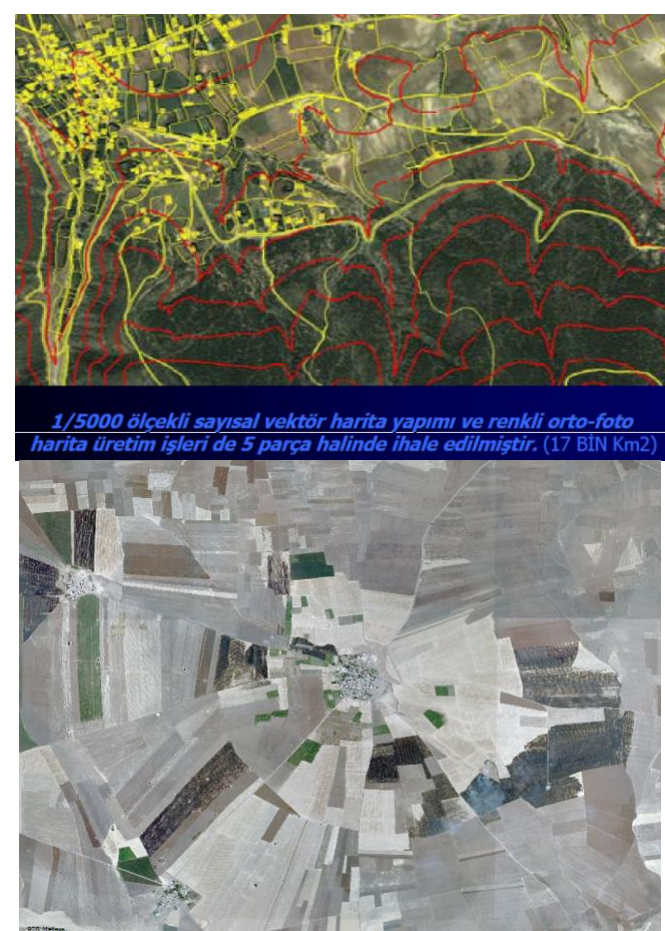

Figure 5. ARIP project context, photogrammetric map and orthophoto

$1 / 5000$ scale photogrammetric maps started production in base maps, especially the simplification and expansion of geodetic measurement systems, as well as the location of the image with the development of technologies that have left orthophoto maps. In urban areas, to have found a more intensive use of space, $1 / 1000$ scale photogrammetric map production is concentrated.

\section{Image Layer Needs}

Layers of spatial information systems, which is one of the indispensable base layer image, obtained by means of remote sensing satellite images and / or aerial photographs produced (Figure 6). Satellite photographs of the scope, content, accuracy, together with the availability of aerial photographs examined in many studies. In case of aerial photographs to create the ultimate purpose facilities, the fastest and most reliable source base is essential in the production costs are determined to be more appropriate than the satellite pictures. 


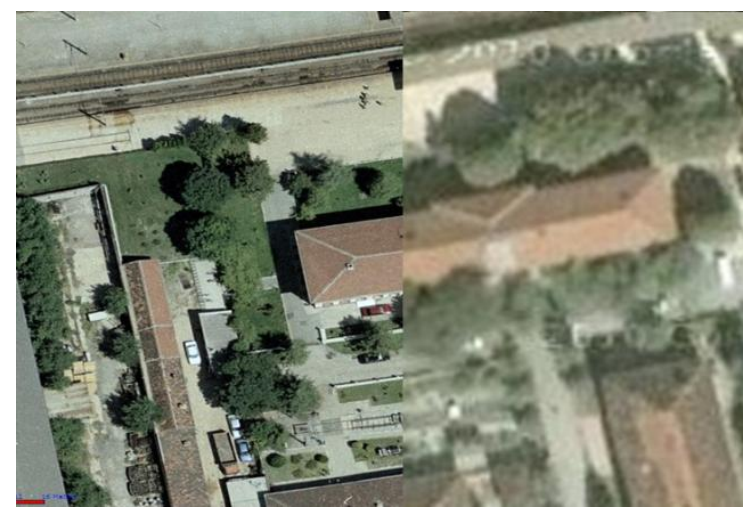

Figure 6. Aerial photo and satellite image

In addition to the inspections carried out to meet the common needs of different institutions and organizations clear, reliable and up to date aerial photographs and orthophoto images and intermediate products produced from these photographs (digital elevation model, etc.) understood needed.

LRCMP has become very necessary and important project after the completion of the cadastre and financed by the World Bank and the Revolving Fund funded sources. After this project will allow the development of service standards and human resources, all of cadastre and spatial data infrastructure will need to be transferred to digital media to be used in all institutions and organizations will become.

Constituted the most important elements of the following topics when LRCMP starts.

- which is subjected to a preliminary examination footers existing layout-to-date current status of land, do not correspond exactly to,

- How is a substitution,

- can not be solved with the digitization of dissolved,

- whether it is necessary renovation,

The status of land are currently being decided as a priority clear and quickly obtain the full agenda.

This project is meeting the needs of both the institution and the other institutions and organizations in the country are carried out with the aim of creating spatial base projects. (http://www.tkgm.gov.tr).

\section{Resources and Public-Private Sector Working Model}

The following sources exist within the body of GDLRC (Figure 7).

- A sufficient number of competent and experienced human resource

- GPS / IMU-aided digital camera mounted on the DMC-1 aircraft

- 100 Terabyte storage for storing images and orthophotos
- $\quad$ Flight plan, the GPS / IMU calculations, digital image processing, photogrammetric triangulation, digital elevation model generation, stereo evaluation, orthophoto production software and hardware

- Display the web service software and hardware

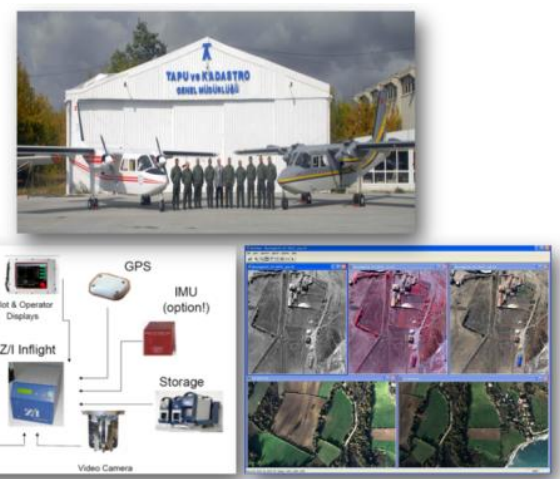

Figure 7. Aerial photo taking staff and equipment

While performing these production activities, potential of private sector is used in addition to GDLRC's own resources.In this context, following works are carried out;

- geodetic studies by the private sector

- Aerial image acquisition by GDLRC

- GPS / IMU data evaluation by GDLRC

- Digital images processing by GDLRC

- photogrammetric triangulation by the private sector

- the creation of digital elevation model by the private sector

- orthophoto production by the private sector

GDLRC staff at every stage, project management, consulting and fulfills the task of supervision. Provide timely and accurate completion of the processes in this way, continuously monitors the accuracy and quality criteria.

\section{Digital Color Orthophoto Production and Costs}

From the inception of intensive and extensive studies across the country, approximately $210,000 \mathrm{~km}^{2}$ area of $1 / 5000$ digital color orthophoto images were produced (Figure 8-9).

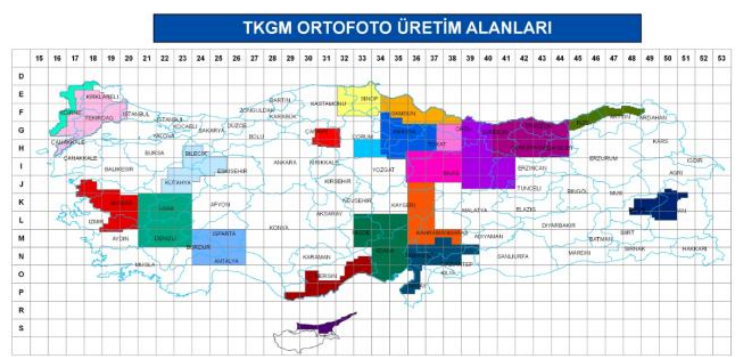

Figure 8. 1:5000 scale digital color orthophoto production areas 
With the private sector to contribute to the process in 11 different regions across the country, the total area of $145000 \mathrm{~km}^{2}$, orthophoto production were carried out. GDLRC the same period, $20000 \mathrm{~km}^{2}$ area with its own staff and equipment, all the processes of six different studies carried out in the area orthophoto production (http://www.tkgm.gov.tr). In this way, the organization's ability to use current technology to track and kept at the highest level.

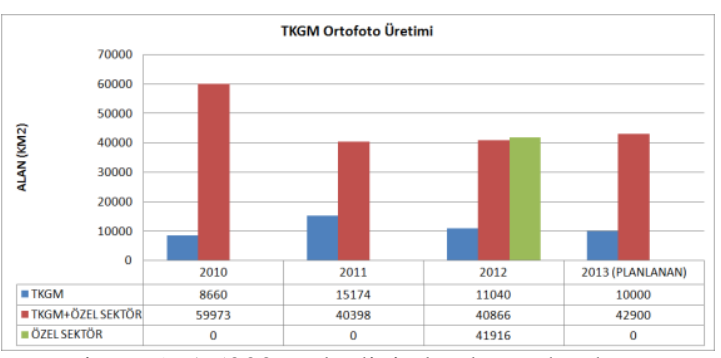

Figure 9. 1:5000 scale digital color orthophoto production amount

In 2012 two regions orthophoto generation, image retrieval has been given to the private sector, including operations. With this approach, work is continuing to increase its production capacity.

Orthophoto production in 2013 will be the size of an area of $40000 \mathrm{~km}^{2}$.

Before bringing digital camera into the institution, orthophoto production work, making the classic photogrammetry, geodetic studies have been conducted according to the methodology. This intensive and time consuming work in the field to the costs of the project has been quite a lot of influence.

\begin{tabular}{|c|c|c|c|c|}
\hline PROJECT & YEAR & SHEET & Work Model & AREA $\left(\mathrm{km}^{2}\right)$ \\
\hline ADANA-1 & 2009 & 1914 & TKGM+Private Sector & 11484 \\
\hline izMiR-1 & 2009 & 2745 & TKGM+Private Sector & 16470 \\
\hline TOPLAM & & 4659 & & 27954 \\
\hline Average Cost & & & $\mathrm{TL} / \mathrm{km}^{2}$ & 59.80 \\
\hline ADANA-2 & 2010 & 2084 & TKGM+Private Sector & 12504 \\
\hline ANTALYA & 2010 & 2400 & TKGM+Private sector & 14400 \\
\hline CORUM-1 & 2010 & 2311 & TKGM+Private Sector & 13866 \\
\hline ESKIȘEHIR & 2010 & 2158 & TKGM+Private Sector & 12948 \\
\hline TOPLAM & & 8953 & & 53718 \\
\hline Average Cost & & & $\mathrm{TL} / \mathrm{km} 2$ & 34.80 \\
\hline ELBISTAN & 2011 & 2428 & TKGM+Private sector & 14568 \\
\hline SAMSUN & 2011 & 1620 & TKGM+Private Sector & 9720 \\
\hline SiNOP & 2011 & 1550 & TKGM+Private Sector & 9300 \\
\hline TOPLAM & & 5598 & & 33588 \\
\hline Average Cost & & & $\mathrm{TL} / \mathrm{km} 2$ & 28.45 \\
\hline & & & & \\
\hline EDIRNE & 2012 & 2664 & TKGM+Private Sector & $159 \mathrm{~B}$ \\
\hline SIVAS & 2012 & 2170 & TKGM+Private Sector & 13020 \\
\hline TOPLAM & & 4834 & & 29004 \\
\hline Average cost & & & $\mathrm{TL} / \mathrm{km} 2$ & 21.85 \\
\hline & & & & \\
\hline Divriăi & 2012 & 3494 & Private Sector & 20964 \\
\hline TRABZON & 2012 & 3492 & Private Sector & 20952 \\
\hline TOPLAM & & 6986 & & 41916 \\
\hline Average cost & & & $\mathrm{TL} / \mathrm{km2}$ & 51.63 \\
\hline & & & & \\
\hline UȘAK & 2013 & 3600 & TKGM+Private Sector & 21600 \\
\hline ADANA & 2013 & 3550 & TKGM+Private Sector & 21300 \\
\hline TOPLAM & & 7150 & & 42900 \\
\hline Average Cost & & & $\mathrm{TL} / \mathrm{km} 2$ & 17.09 \\
\hline
\end{tabular}

Table 1. Average procurement cost
Geodetic studies, photogrammetric triangulation studies, digital elevation model and orthophoto production cost for the initial stages of projects carried out in 59.80 $\mathrm{TL} / \mathrm{km}^{2}$. Then, using all the opportunities of technology and national projects (GPS / IMU-aided digital camera, TUSAGA-Active system, the outputs of the projects on a national scale and so on.) have been studied. In this context, the production costs of the studies (Table 1) $\mathrm{TL} / \mathrm{km}^{2} 34.80$ in 2010 , TL/ $\mathrm{km}^{2} 28.45$ in $2011, \mathrm{TL} / \mathrm{km}^{2}$ 21.85 in 2012, TL/km² 17.09 in 2013 (Figure 10).

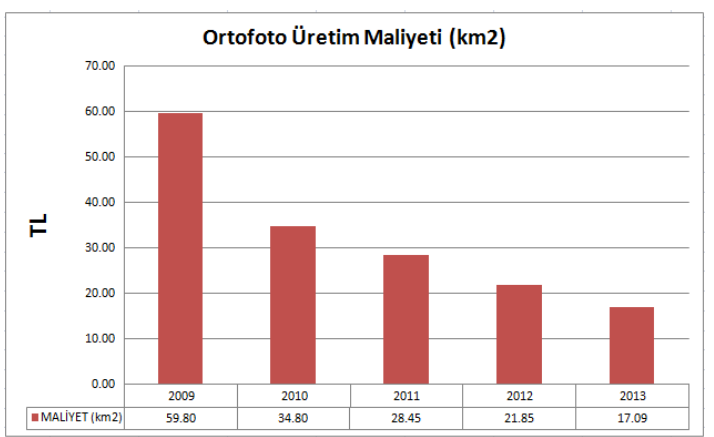

Figure 10. Average procurement cost by year

\section{Cost-Effectiveness Analysis}

Costs Inter-ministerial Coordination and Planning Committee Map Jobs (BHIKPK) deals, budget expenditures and estimated costs related to the works tenders in general, comparisons are made, the total cost of production is increasing in spatial data. This increase is due to the technological costs. However, with the increase in production costs, along with the development of technology and the change has decreased greatly, and the unit costs. Increase in output in terms of change in through technology products, such as the quantity as well as quality is increased. Increasing the amount of production in terms of quantity, more production is achieved in less time. Computerized checks and calculations done in the sense of qualifications considering increases in production decline rate of error that occurred, or could prevent the emergence of extra costs.

Continuously increasing demands on the production line with the requirements of spatial data. In order to protect the information obtained up to date with the rapidly evolving and changing technology in the production of spatial data updated.

Cost-effective analysis was obtained at the total and unit costs and production volumes by years analyzed, not only of increased demand for the production of spatial data is one of the indicators. However, the rate of urbanization is increasing rapidly increasing population brings with it. Thus, demand is increased day by day.

If we consider the natural disasters in today's world of increased production of spatial data is becoming more important. In that regard, has been following the 
Marmara earthquake MEER project made for the purpose of agrarian reform ARIP support the work of the project, updating the information about the property in the name of the LRCMP projects. The total costs can be demonstrated in the material sense, of course, but while comparing the social benefits and costs clearly defined, it is very difficult to calculate. While one might be put in place and compensate for losses in the material sense in this case, the small losses that may occur in the social sense, rather than in terms of cost, even initiating the impossible (Çolak et all., 2012).

\section{Product Content and Quality}

Digital camera DMC panchromatic, color and nearinfrared imagescan be obtained in real time. (Figure 11). Images, the spectral sensitivity Blue: $400-580 \mathrm{~nm}$, Green: 500-650 nm, Red: 590-675 nm and near infrared: 675$850 \mathrm{~nm}$ radiometric resolution is 12 -bit.

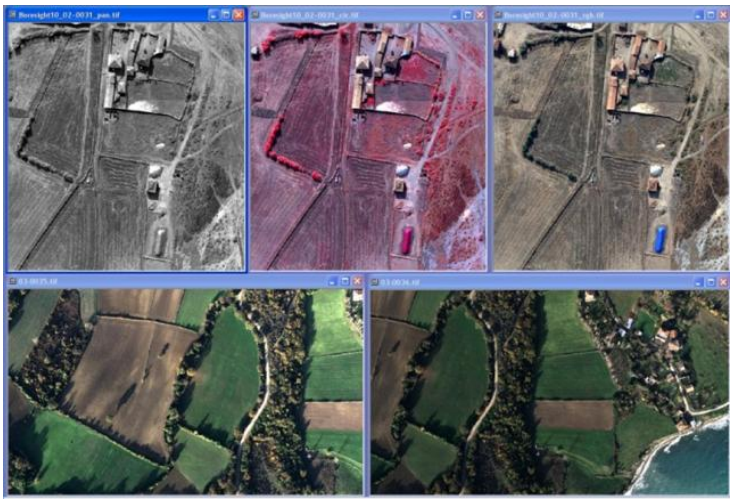

Figure 11. Images from digital camera

The size of each pixel in the images 12 micron and the spatial resolution of images obtained from a height of $3000 \mathrm{~m}$ from the land GSD $=30 \mathrm{~cm}$. Months from May to October, when the sun is perpendicular to a full $99.9 \%$ of the images obtained from the studies is clear.

Geodetic studies, and GPS / IMU data used in assessments TUSAGA-active. Thus, the positional accuracy of 1-2 $\mathrm{cm}$ with the ground control points are studied.

In this context, the positional accuracy for the photogrammetric triangulation evaluation activities is close to one-quarter of the size of pixels and the height accuracy of $1 / 3$ pixel is obtained (Selçuk et all., 2011).

Indicating that the morphological characteristics of the land prior to the production of digital elevation model data (road, river, slope, peak, and so on.) is obtained by means of the operators, and then automatically elevation points collected and areas with incomplete or incorrect adjustments are made with a skill of the operator.

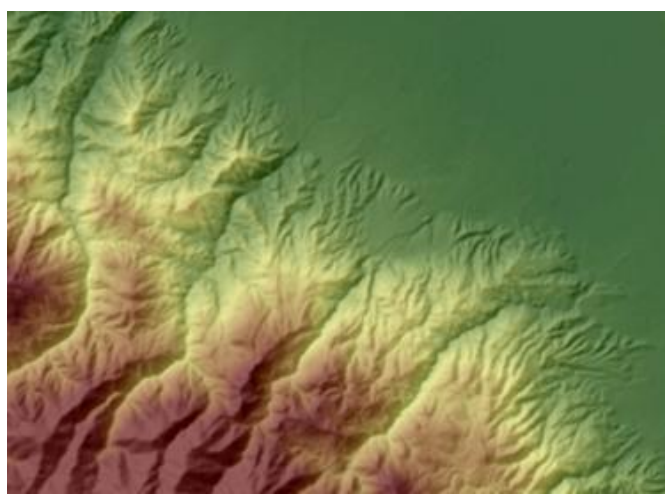

Figure 12. Digital elevation model

This is a leading indicator of spatial data base together with the need for precise elevation model is created. (Figure 12).

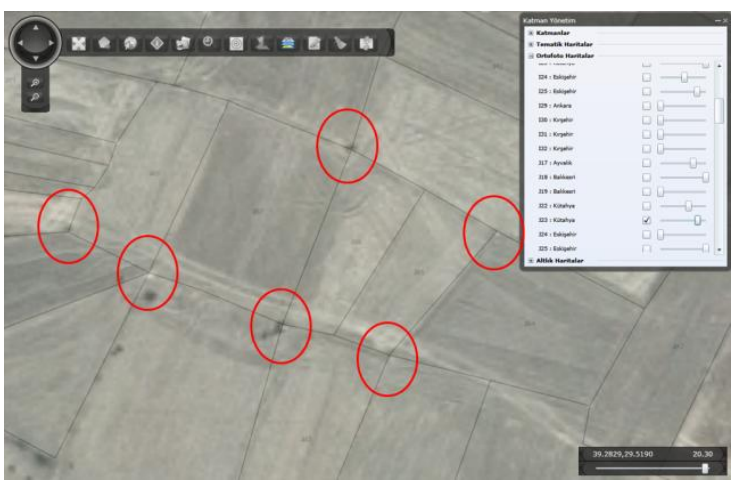

Figure 13. Orthophoto and cadastre parcel corners

Production of the size of the pixels may be 1-1.5 ortofotolarda position accuracies (Figure 13).

\section{Orthophoto Web Services}

Orthophotos are prepared under OGC standards and published as web services (Figure 14) (http://www.tkgm.gov.tr).

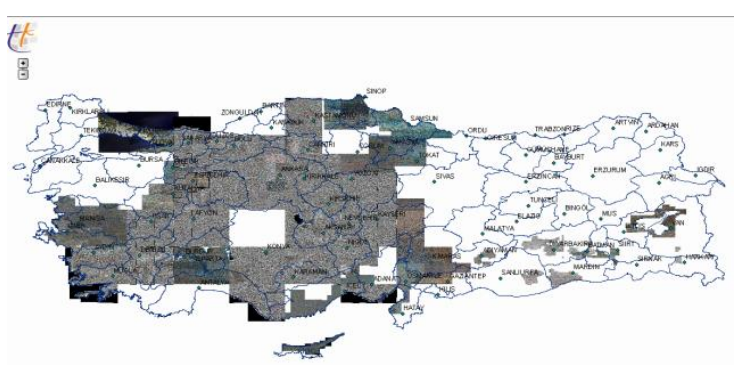

Figure 14. Orthophoto web services

Orthophoto services intensively used in decision support and control during renovation cadastral work. Renovation work planned in areas with existing cadastral orthophotos superposed sheets, after digitization. Also the current status of the region is obtained by field studies, digitized maps and orthophotos are superposed. So that the entire system can be controlled, implementation decisions can be taken more quickly (Figure 15). 


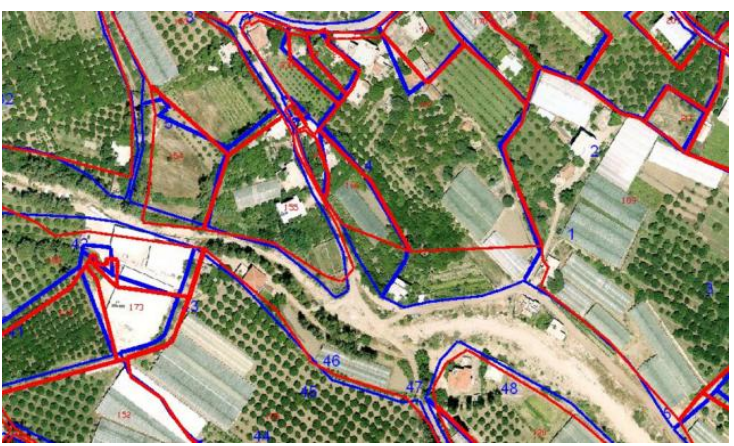

Figure 15. Purchase of land parcels created by digitization and the overlapping of the orthophoto

Spatial digitization of cadastre and land registry information is also prepared for the integration of real estate System (MEGSIS) orthophoto services will be provided access to the system, the location and the quality of the integrated cadastral parcels are checked immediately (Figure 16).

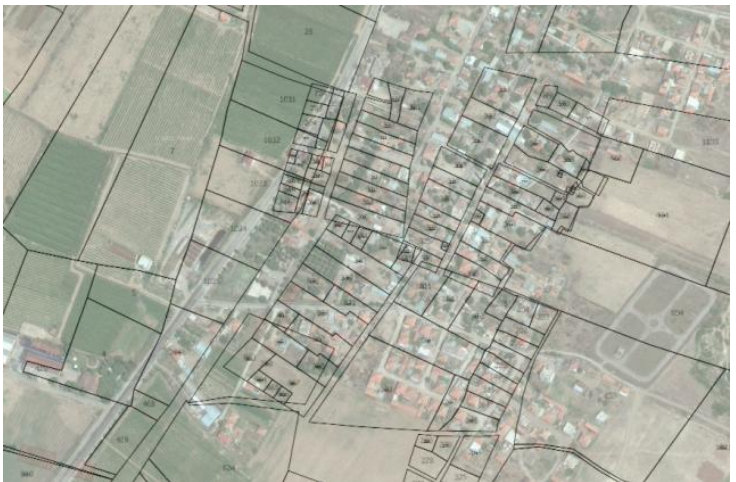

Figure 16. MEGSIS ve orthophoto web service

Accesses from outside the organization for the safety of the system is provided with a static IP control. All institutions and organizations can benefit from the orthophoto web services .

During the field studies through the notebook and the appropriate GPS receiver units access to orthophoto web services can be done and interactive data production can be performed (Figure 17).

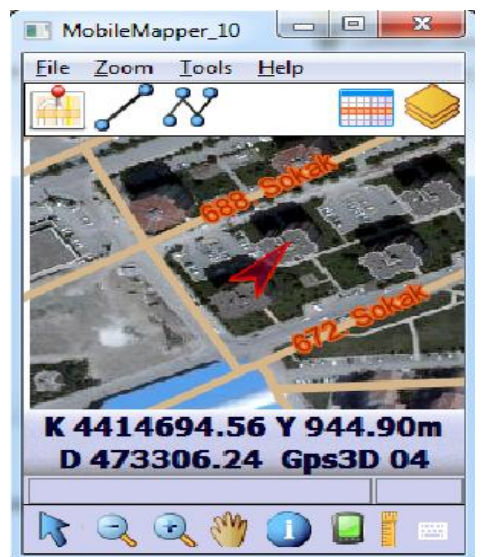

Figure 17. GPS hand unit and orthophoto web service

\section{Studies with institutions and organizations engaged in production of orthophoto}

Until 2008, the institutions and organizations (Bank of Provinces General Directorate of Agrarian Reform, DSI General Directorate of Highways General Directorate of Forestry, Metropolitan Municipalities) meet their image needs from satellite images of $1.20 \mathrm{~m}$ accuracy and orthophotos produced by private sector. Studies performed to determine the need for TNGIS and institutions, the image base by reaching a common consensus on the content of the reports prepared to meet 1:5000 scale map, the location and height accuracy of $30-50 \mathrm{~cm}$, used in the production of all relevant institutions and organizations have emerged as a partner. (Maraş et all., 2011).

In this context, the two public institutions in 2009, GDLRC and GCM, bodies of facilities in the air, and digital camera, digital color orthophoto production work have increased. The two institutions that meet their needs and to avoid duplication between the "data exchange protocol" done and performing image retrieval in different areas of public interest and taking into consideration the interests of the country have joined forces. GDLRC, GSD $=30 \mathrm{~cm}, \mathrm{HGK}, \mathrm{GSD}=45 \mathrm{~cm}$ resolution orthophoto production of images covering the whole country by continuing to work.

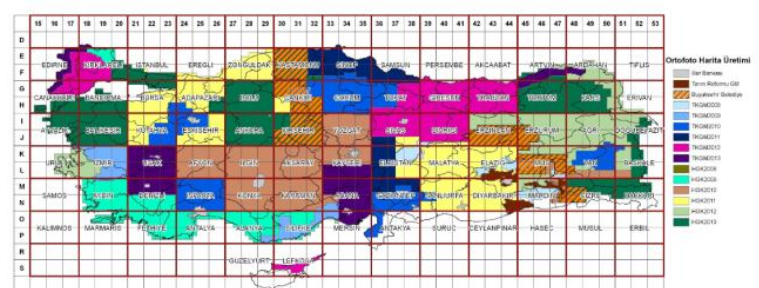

Figure 18. Orthophoto product area

Orthophotos covering areas found within the organization, but in other institutions, the web service protocols, change and / or are provided by way of purchase, and are available as a web service with orthophotos (Figure 18).

That the contents of the digital color orthophoto production 1:5000 scale maps and digital elevation model data, all public institutions and organizations are in need.

\section{Historical Aerial Photographs}

Digital orthophoto production of aerial photographs in the old part of the project is carried on. These studies cadastral digital cadastre and land registry information and studies to support the acceleration of the rehabilitation and upgrading works to constitute a base for decision support processes are performed with the aim 
to speed up. The provinces of Ankara and Istanbul's historic aerial photographs and orthophoto production has prepared as web services (Figure 19).

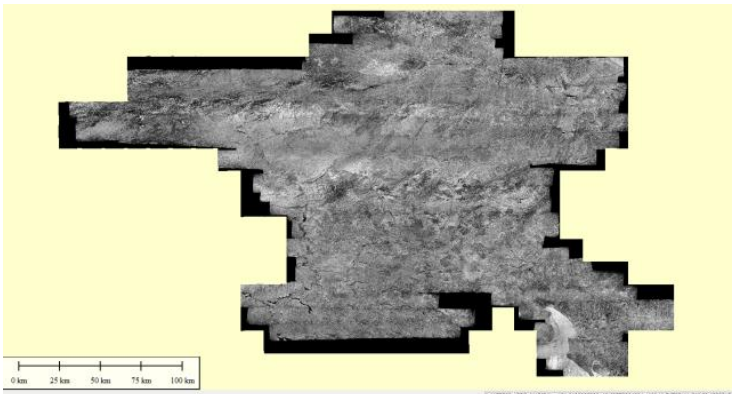

Figure 19. Orthophoto from old dated aerial photographs Ankara

In this context, the old dated;

- 1:35000 scale aerial photographs and digital images obtained by scanning images using ground control points on the digital orthophoto production will be determined approximately.

- Various scale aerial photographs and scanned to obtain digital images with approximately coordinate information,

- 1:16000 scale aerial photographs and digital images obtained by scanning images using ground control points will be determined on the production of digital orthophoto

studies have been conducted. The orthophotos produced as a result of all this work will serve as web services, can easily be used by the related parties.

\section{Daily Reflections}

First stage technology costs, caused by a large increase of total costs, though, according to the results obtained in terms of product quality and quantity of output growth is provided, it greatly reduces the cost of the unit. Possible to calculate the costs of production output as the product of spatial data, although in terms of cost-effectiveness is very difficult to reveal the social costs mentioned. However, when we consider the data obtained from the contributions of social life can be said that a reasonable level of bearable costs (Çolak et all., 2012).

GDLRC studies, public institutions and organizations dealing with spatial data, the private sector, universities and projects are also very close to the peripheral countries plays an important role in the spatial connection.

Overall, 1:5000 scale digital color orthophoto production;

- Human resources development

- Current technologies can be applied, and followed-up

- Latest technologies, quality, production capacity is up to date digital maps are created
- Studies of large quantities of satellite image need is minimized, even ended

- Color, near-infrared images are provided, in advanced stages of product types are planned to increase

- Near-infrared images enables the use of remote sensing techniques provided

- Universities provided with the latest technologies, research and development facility

- orthophoto is provided for TNGIS

- land cadastre renovation work status of the control mechanism using a decision-support and strengthened

- Display all the projects carried out by the Authority, provided base support

- Natural disasters and emergencies digital map production is carried out as soon as the available data

- Orthophoto of institutions and organizations in need of web services, services provided to the private sector because it is out of service

- Public institutions and organizations, the possibility to access the needed information quickly finding spatial

- Stereo evaluation with the possibility of dams, roads and so on. studies used in the project work

- Display manufacturing industry base in balance

- capacity of the private sector creating jobs throughout the season for the sector is provided and qualified personnel grown more

- successful completion of the projects with the World Bank, etc., and because it is a good performance received the trust and support of organizations

- model establishes the near and distant countries, consulting and auditing services provided

- establishes support for the private sector to take part in the international projects and quality, providing a capacity of finishing the job.

Initiated with the aim to achieve the numerical pad image color orthophoto production 1:5000 final products of the work, from the air images, orthophotos and digital elevation model produced a wide range of uses in the data (Kisa et all., 2011).

\section{Result}

GDLRC projects since the 1950s, perpetuated by continuing production of spatial data successfully. Data quality materials and the latest technology, in order to obtain up to date and accurate work, the institution, to ensure that the use of remote sensing technologies to the benefit of the country continues to work.

Spatial data infrastructure increases the orthophoto production in terms of quantity and quality, to ensure the transition should be provided quickly changing and developing the latest technological innovations, the necessary steps should be discarded and a sufficient level to be reached as soon as possible. 
Municipalities, many public institutions and the private sector need orthophotos. Projects needed for the production of orthophoto maps with features and location information to the air intake of the image have strategic importance such as (Çolak et all., 2012) :

- Since there is only an estimated 60 to 70 days in a year as 'flight working day', aerial image acquisition must be performed within tihs period

- If cancelled bidding process considering the procurement of services with the private sector as a result of extension of the tender process and avoid demand 'flight business days' aerial image in deficits, as a result, in the case of defects in the projects in terms of cost and time savings sağlanamayıp will result in a waste of resources,

- Natural disasters, aerial imagery urgently needed to cover the case of public support for the decision-making mechanisms in the public sector, and there could be delays, problems that may occur as a result of no return in terms of social costs,

Public institutions and the private sector in our country, renewing itself goes to increase capacity. Follow-up and planning of rapid change in urban areas, provide facility to be made in terms of valuation of land, the image is used as a base oblique photogrammetry and products in addition to the use of orthophotos studies show that the development of our country. In this context, all kinds of GDLRC to follow technological developments, in terms of both hardware and human resources capacity building work is done.

\section{References}

Çolak, S., 2012, "Mekansal Veri Üretiminde Maliyet Etkinlik Analizi ve Yansımaları", GDLRC Uzmanlık Tezi, Ankara

Kısa, A., Bakıcı, S., Erkek B., Özmüş, L., Tufan, T., 2010, "Tapu ve Kadastro Genel Müdürlüğünde Fotogrametrik Gelişmeler”, III. Uzaktan Algılama ve Coğrafi Bilgi Sistemleri Sempozyumu (UZALCBS’2010), 11-13Ekim 2010, Gebze Kocaeli

Kısa, A., Bakıcı, S., Erkek, B., Özmüş, L., Tufan, T., 2010, "Ortofoto Bilgi Sistemi, Tapu ve Kadastro Modernizasyon Projesi'ndeki Yeri ve Önemi”, III. Uzaktan Algılama ve Coğrafi Bilgi Sistemleri Sempozyumu (UZALCBS'2010), 11-13 Ekim 2010, Gebze Kocaeli

K1sa, A., Bakıc1, S., 2011, "Spatial Data Infrastructure in Turkey and Projects", FIG Working Week 2011, 18-22 May 2011 Marrakech, Morocco

Maraş, H., Aşık Ö., Yılmaz, A., Kısa, A., 2011, “Türkiye Ulusal Ortofoto Bilgi Sistemi ve Gerçekleştirilen Çalışmalar”, TMMOB Harita ve Kadastro Odası 13.
Türkiye Harita Bilimsel ve Teknik Kurultayı, 18-22 Nisan 2011, Ankara

Selçuk, O., Bakıcı, S., Kısa, A., Tufan, T., Açar, F., Tuna, H., 2011, "GPS/IMU Verilerinin Varlığında Yer Kontrol Noktalarının Kullanımı”, TUFUAB VI Teknik Oturumu, 23-26 Şubat 2011, Antalya

Kısa, A., Çolak, S., Bakıcı, S., Özmüş, L., 2012, “Tapu ve Kadastro Ortofoto Üretim Faaliyetleri ve Güncel Yansımaları", TUFUAB VII Teknik Oturumu, 23-25 Mayıs 2012, Trabzon

LRCMP Raporu, GDLRC Harita Dairesi Başkanlığı, 2012, Ankara

http://www.tkgm.gov.tr

http://inspire.jrc.ec.europa.eu/ 